\title{
Sita Umum Kepailitan Mendahului Sita Pidana dalam Pemberesan Harta Pailit
}

\author{
Siti Hapsah Isfardiyana*
}

\begin{abstract}
Abstrak
Penyitaan dalam perkara pidana bertujuan untuk kepentingan pembuktian terutama ditujukan sebagai barang bukti dalam penyelidikan/penyidikan, pada tingkat penuntutan, dan tingkat pemeriksaan di pengadilan. Semua penyitaan yang dilakukan menjadi hapus ketika harta sudah disita umum. Benda yang berada dalam sitaan karena perkara perdata atau karena pailit dapat juga disita untuk kepentingan penyidikan, penuntutan, dan mengadili perkara pidana. Masalah yang dibahas dalam artikel ini adalah manakah yang harus didahulukan apabila debitor sudah diputus pailit oleh hakim, namun ternyata hartanya juga terkait kasus tindak pidana dan dilakukan sita pidana oleh penyidik. Sita umum kepailitan mendahului sita pidana karena kreditor harus segera mendapatkan haknya dan negara tidak perlu khawatir karena kurator dapat menjamin negara ditempatkan sebagai kreditor pemegang hak istimewa untuk selalu didahulukan pemenuhan kewajibannya.
\end{abstract}

Kata kunci: debitor pailit, kepailitan, kurator, sita pidana, sita umum.

\section{General Bankruptcy Confiscation Precede Criminal Confiscation in the Bankruptcy Estate Settlement}

\begin{abstract}
Confiscation in a criminal case aims for proving matters, primarily intended as evidence in the inquiry/investigation, prosecution rate, and the level of examination in court. All confiscations conducted in criminal case becomes cleared when the property has been confiscated in the general confiscation. Objects that are confiscated by the civil suit or bankruptcy can also be seized for the purpose of criminal investigation and prosecutions. This article discusses which one that should be taken as precedence if the debtor has been declared bankrupt by the judge, while her/his assets is also related to criminal case and has been confiscated by prosecutors. General confiscation precede criminal confiscation, because creditors must soon get their rights and the state, as a matter of criminal investigation, does not need to worry because curator can guarantee that the state is placed as the holder of the privilege to always take precedence over the fulfillment of its obligations.
\end{abstract}

Keywords: bankruptcy assets, bankruptcy, curator, criminal confiscation, general confiscation.

PADJADJARAN Jurnal IImu Hukum Volume 3 Nomor 3 Tahun 2016 [ISSN 2460-1543] [e-ISSN 2442-9325]

Dosen Tetap Fakultas Hukum Universitas Islam Indonesia, Jl. Tamansiwa No. 158 Yogyakarta 55151-Telp. (0274) 379178, Fax. (0274) 377043, dianhapsah@gmail.com, S.H., M.H. (Universitas Islam Indonesia). 


\section{A. Pendahuluan}

Pailit adalah suatu keadaan di mana seseorang berhenti, tidak mampu lagi membayar hutangnya melalui putusan Hakim atau Pengadilan Negeri. ${ }^{1}$ Kepailitan di Indonesia diatur dalam Undang-Undang Republik Indonesia Nomor 37 Tahun 2004 tentang Kepailitan dan Penundaan Kewajiban Pembayaran Utang (UU KPKPU). UU KPKPU menyebutkan bahwa kepailitan adalah sita umum atas semua harta kekayaan debitor pailit yang pengurusan dan pemberesannya dilakukan oleh kurator di bawah pengawasan hakim pengawas sebagaimana diatur di dalam undang-undang ini. ${ }^{2}$

Harta debitor pailit yang disita umum adalah seluruh kekayaan debitor pada saat pernyataan pailit diucapkan serta segala sesuatu yang diperoleh selama kepailitan ${ }^{3}$ dengan pengecualian sebagai berikut:

1. benda, termasuk hewan yang benar-benar dibutuhkan oleh Debitor sehubungan dengan pekerjaannya, perlengkapannya, alat-alat medis yang dipergunakan untuk kesehatan, tempat tidur dan perlengkapannya yang dipergunakan oleh Debitor dan keluarganya, dan bahan makanan untuk 30 (tiga puluh) hari bagi Debitor dan keluarganya, yang terdapat di tempat itu;

2. segala sesuatu yang diperoleh Debitor dari pekerjaannya sendiri sebagai penggajian dari suatu jabatan atau jasa, sebagai upah, pensiun, uang tunggu atau uang tunjangan, sejauh yang ditentukan oleh Hakim Pengawas; dan

3. uang yang diberikan kepada Debitor untuk memenuhi suatu kewajiban memberi nafkah menurut undang-undang. ${ }^{4}$

Sejak putusan pailit diucapkan, debitor demi hukum kehilangan haknya untuk menguasai dan mengurus kekayaan yang termasuk harta pailit. ${ }^{5}$ Sita umum bertujuan untuk melindungi kepentingan kreditor terhadap perbuatan debitor yang dapat merugikan harta pailit dan menghentikan eksekusi harta debitor oleh para kreditornya untuk memenuhi haknya masing-masing. Hal ini juga dapat memaksimalkan pengumpulan harta pailit guna pembayaran kepada seluruh kreditor. Dengan demikian, hutang dapat dibayar maksimal dan menjaga hak para pihak, menjaga debitor tidak dapat menggelapkan atau membawa barangbarangnya dari kreditor, serta melindungi kreditor-kreditor konkuren lainnya. Harta debitor yang disita umum akan dikelola oleh kurator, diawasi oleh hakim pengawas. Kewenangan pengelolaan harta palit berpindah ke tangan kurator karena debitor dianggap sudah tidak cakap hukum. Kurator akan membagikan harta debitor

M. Marwan dan Jimmy P., Kamus Hukum Dictionary Of Law Complete Edition, Cetakan I, Surabaya: Reality Plubisher, 2009, hlm. 475.

Pasal 1 angka UU KPKPU.

Pasal 21 UU KPKPU.

Pasal 22 UU KPKPU.

Pasal 24 UU KPKPU. 
kepada para kreditornya secara merata sesuai dengan besar piutang masingmasing. Semua penyitaan yang dilakukan menjadi hapus kemudian beralih menjadi sita umum kepailitan. Apabila kurator sudah selesai membereskan harta debitor palit, maka berakhirlah proses pailit.

Sita umum merupakan bentuk penyitaan yang dikenal dalam hukum perdata khususnya hukum kepailitan yang mengatur hubungan antar-individu yang bersifat privat. Hukum publik dalam hal ini hukum pidana juga mengenal sita yang dikenal dengan 'sita pidana'. Sita pidana dalam Kitab Undang-Undang Hukum Acara Pidana (KUHAP) disebut dengan penyitaan. Penyitaan dalam KUHAP didefinisikan sebagai serangkaian tindakan penyidik untuk mengambil alih dan/atau menyimpan di bawah penguasaannya benda bergerak atau tidak bergerak, berwujud atau tidak berwujud untuk kepentingan pembuktian dalam penyidikan, penuntutan, dan peradilan. ${ }^{6}$ Pasal 42 ayat (1) KUHAP menyebutkan bahwa penyidik berwenang memerintahkan kepada orang yang menguasai benda yang dapat disita, menyerahkan benda tersebut kepadanya untuk kepentingan pemeriksaan dan kepada yang menyerahkan benda itu harus diberikan surat tanda penerimaan. Penyitaan dalam perkara pidana bertujuan untuk kepentingan pembuktian terutama ditujukan sebagai barang bukti dalam penyelidikan atau penyidikan, tingkat penuntutan dan tingkat pemeriksaan di pengadilan. ${ }^{7}$ Benda yang dikenakan penyitaan dapat dikembalikan apabila:

a. kepentingan penyidikan dan penuntutan tidak memerlukannya lagi;

b. perkara tersebut tidak jadi dituntut karena tidak cukup bukti atau ternyata bukan merupakan tindak pidana;

c. perkara tersebut dikesampingkan untuk kepentingan umum atau perkara tersebut ditutup demi hukum, kecuali apabila benda itu diperoleh dari suatu tindak pidana atau yang dipergunakan untuk melakukan suatu tindak pidana.

Apabila perkara sudah diputus, maka benda yang dikenakan penyitaan dikembalikan kepada orang atau kepada mereka yang disebut dalam putusan tersebut kecuali jika menurut putusan hakim benda itu dirampas untuk negara, untuk dimusnahkan atau untuk dirusakkan sampai tidak dapat dipergunakan lagi atau jika benda tersebut masih diperlukan sebagai barang bukti dalam perkara lain. ${ }^{8}$

Dalam praktik, harta pailit yang telah disita umum dan telah diurus dan/atau dibereskan oleh kurator, ternyata dapat diambil alih oleh penyidik untuk disita pidana. Penyidik melakukan penyitaan karena terdapat indikasi bahwa harta

Pasal 1 angka 16 KUHAP.

Andi Sofyan dan Abd. Asis, Hukum Acara Pidana Suatu Pengantar, Cetakan ke-2, Jakarta: Prenadamedia Group, 2014, hlm. 156.

Pasal 46 ayat (2) KUHAP. 
tersebut terkait dengan tindak pidana korupsi dan pencucian uang. ${ }^{9}$ Benda yang berada dalam sitaan karena perkara perdata atau karena pailit dapat juga disita untuk kepentingan penyidikan, penuntutan, dan mengadili perkara pidana. ${ }^{10} \mathrm{Harta}$ benda yang disita dalam perkara perdata namun mempunyai kaitan dengan tindak pidana yang sedang diperiksa, dapat disita oleh penyidik.

Salah satu kasus yang terkait dengan harta pailit yang dilakukan sita pidana adalah kasus PT. Sinar Central Rejeki melawan Bareskrim Mabes Polri. Pada tanggal 31 Juli 2009 PT. Sinar Central Rejeki telah diputus pailit oleh Pengadilan Niaga Jakarta Pusat berdasar Putusan Nomor 26/Pailit/2009/PN.Niaga.Jkt.Pst. Pada saat dilakukan pemberesan harta pailit melalui sita umum, terjadi penyitaan harta pailit oleh Bareskrim Mabes Polri.

Bareskrim Mabes Polri menyita Plaza Serpong terkait kasus tindak pidana pencucian uang yang melibatkan Robert Tantular, Hartawan Alwy, dan Anton Tantular dalam kasus tindak pidana pencucian uang dana penipuan dan penggelapan dana nasabah PT. Antaboga Deltasekuritas Indonesia pada Bank Century berdasarkan penetapan PN Tangerang Nomor 682/PEN.PID.SITA/2009/TNG pada tanggal 23 Maret 2009. ${ }^{11}$ Penyitaan terkait Robert yang menempatkan dana tersebut di PT. Sinar Central Rejeki, perusahaan yang bergerak di bidang pengembang. Dana yang terkumpul tersebut kemudian digunakan untuk melakukan pembangunan Mal Serpong dan pembelian aset lainnya. Nilai aset Mal Serpong diduga mencapai Rp 312 miliar. ${ }^{12}$ Oleh karena itu, kurator PT. Sinar Central Rejeki, Wahyudi Dewantara, S.H. menggugat Bareskrim Mabes Polri dengan alasan telah menyita harta pailit PT. Sinar Central Rejeki. Penyitaan ini berakibat pada pemberesan harta pailit yang seharusnya dapat segera diselesaikan menjadi berhenti di tengah jalan.

Akibat dari harta pailit yang disita oleh penyidik adalah pemberesan harta tersebut tidak dapat dilakukan. Pada akhirnya,perlindungan atau jaminan atas pembayaran piutang kepada para kreditornya tidak dapat terpenuhi. Terdapat tumpang tindih antara hukum pidana dengan hukum perdata khususnya dalam hukum kepailitan. Hukum perdata mengatur bahwa semua penyitaan yang dilakukan menjadi hapus ${ }^{13}$ kemudian beralih menjadi sita umum kepailitan. Hukum pidana mengatur bahwa benda yang berada dalam sitaan karena perkara perdata atau karena pailit dapat juga disita untuk kepentingan penyidikan, penuntutan, dan

Lebih jelas mengenai tindak pidana pencucian uang lihat Romli Atmasasmita, "Analisis Hukum Undang-Undang Nomor 8 Tahun 2010 Tentang Pencegahan Tindak Pidana Pencucian Uang", Padjadjaran Jurnal Ilmu Hukum, Volume 3 Nomor 1, 2016, hlm. 1-23.

Pasal 39 ayat (2) KUHAP.

Kompas, http://nasional.kompas.com/read/2012/11/05/15163281/Mal.Serpong.Robert.Tantular.Diserahkan.ke.Kejagung diakses 15 Maret 2017, Pukul 14:55 WIB.

Ibid.

Pasal 31 ayat (2) UU KPKPU. 
mengadili perkara pidana. ${ }^{14}$ Pada keadaan seperti ini, mana yang harus didahulukan apabila debitor sudah diputuskan pailit oleh hakim, akan tetapi ternyata harta debitor pailit tersebut terkait kasus tindak pidana dan harta pailit dilakukan sita pidana oleh penyidik. Artikel ini mencoba menjelaskan pilihan tersebut.

\section{B. Pengertian dan Jenis Sita}

Penyitaan berasal dari terminologi Belanda yaitu beslag dan di Indonesia kenal istilah beslah atau bahasa bakunya adalah sita atau penyitaan. ${ }^{15}$ Sita adalah penyitaan atas harta kekayaan milik seseorang, baik barang bergerak atau barang tidak bergerak untuk menjamin hak-hak penggugat dalam perkara perdata atau atas barang-barang untuk mendapatkan bukti dalam perkara pidana. Sita digunakan sebagai jaminan barang di bawah kuasa pengadilan sampai proses perkara selesai. ${ }^{16}$ Menurut M. Yahya Harahap terdapat beberapa pengertian yang terkandung di dalam kata sita atau penyitaan yaitu:

1. Tindakan menempatkan harta kekayaan debitor selama paksa berada ke dalam keadaan penjagaan (to make into custocy the property of defendant);

2. Tindakan paksa penjagaan (custody) itu ditahukan secara resmi (official) berdasarkan permohonan pengadilan atau hakim;

3. Barang yang ditempatkan dalam penjagaan tersebut, berupa barang yang disengketakan, tetapi boleh juga barang yang akan dijadikan sebagai alat pembayaran atas pelunasan hutang debitor atau debitor dengan jalan menjual lelang (executorialverkoop) barang yang disita tersebut;

4. Penetapan dan penjagaan barang yang disita, berlangsung selama proses pemeriksaan, sampai ada putusan pengadilan yang berkekuatan hukum tetap, yang menyatakan sah atau tidak tindakan penyitaan tersebut.

Penyitaan bertujuan untuk mengamankan harta kekayaan debitor karena adanya dugaan kepada debitor, sebelum keputusan hakim yang mengalahkannya dijatuhkan atau boleh dijalankan, mencari akal untuk menggelapkan atau melarikan barangnya, baik bergerak maupun yang tidak bergerak dengan maksud untuk menjauhkan barang itu dari kreditur. ${ }^{17}$ Tujuan pokok dilakukan sita antara lain adalah untuk melindungi kepentingan kreditor dari iktikad buruk debitor sehingga gugatan menjadi tidak hampa (ilusioner), pada saat putusan setelah berkekuatan hukum tetap, serta memberi jaminan kepastian hukum bagi kreditor terhadap kepastian terhadap objek eksekusi, apabila keputusan telah berkekuatan hukum. ${ }^{18}$

\footnotetext{
Pasal 39 ayat (2) KUHAP.

M. Yahya Harahap, Hukum Acara Perdata Tentang Gugatan, Persidangan, Penyitaan, Pembuktian dan Putusan Pengadilan, Cetakan Keempat, Jakarta: Sinar Grafika, 2006, hlm. 282.

Marwan dan Jimmy, Op.cit., hlm. 574.

Pasal 227 HIR jo. 720 Rv.

M. Yahya Harahap, Op.cit., hlm.285-286.
} 
Penyitaan bertujuan untuk menjaga keutuhan dan keberadaan harta debitor selama proses penyelesaian sengketa dan apabila debitor terbukti bersalah, harta tersebut dapat diserahkan kepada kreditor. Harta yang disita dapat langsung diserahkan kepada kreditor ketika yang disengketakan adalah harta yang disita tersebut. Namun, apabila yang disengketakan adalah pembayaran sejumlah uang maka harta tersebut dijadikan sebagai pembayaran dengan cara melelangnya (executorial verkoop) terlebih dahulu. Namun, apabila harta yang disita terkait dengan kasus pidana maka harta tersebut dapat dikembalikan kepada yang punya atau menunggu putusan hakim terlebih dahulu.

Dilihat dari segi teknis peradilan, tujuan penyitaan adalah:

1. Upaya hukum bagi kreditor untuk menjamin dan melindungi kepentingannya atas keutuhan dan keberadan harta kekayaan debitor sampai putusan memperoleh kekuatan hukum tetap;

2. Upaya itu bermaksud untuk menghindari tindakan iktikad buruk (bad faith) debitor dengan berusaha melepaskan diri memenuhi tanggung jawab perdata (civil liability) yang mesti dilakukan atas perbuatan melawan hukum (PMH) atau wanprestasi yang dilakukannya;

3. Secara hukum harta kekayaan tergugat berada dan ditempatkan di bawah penjagaan dan pengawasan pengadilan, sampai perintah pengangkatan atau pencabutan sita;

4. Apabila penyitaan telah diumumkan melalui pendaftaran pada buku register kantor yang berwenang untuk itu sesuai Pasal 198 HIR, maka terhitung sejak tanggal pendaftaran dan pengumuman sita sesuai dengan Pasal $213 \mathrm{R}$. Bg. Oleh karena itu melekat ketentuan sebagai berikut:

a. Pasal 199 HIR dan Pasal 215 R.Bg melarang debitor untuk menjual dan memindahkan barang sitaan kepada siapapun.

b. Pelanggaran atas itu, menimbulkan dua sisi akibat hukum:

1) Akibat hukum dari segi perdata:

Tindakan jual beli atau penindasan hak atau barang tersebut maka tindakan atau perbuatan tersebut batal demi hukum (null and void). Oleh karena itu, status barang tersebut kembali menjadi dalam keadaan semula (status quo) sebagai barang sitaan, sehingga tindakan atau perbuatan pemindahan hak atas barang dianggap tidak pernah terjadi (never existed).

2) Akibat hukum dari segi pidana. Diancam melakukan tindakan pidana Pasal 231 KUHP berupa tindak kejahatan yang dengan sengaja melepas barang yang telah dijatuhi sita menurut peraturan perundang-undangan yang berlaku. Perbuatan tindak kejahatan ini diancam dengan pidana penjara 
maksimal 4 tahun. Tindak kejahatan yang diatur Pasal 231 KUHP adalah tindakan terhadap barang sitaan berupa:

a) Melepaskan barang yang disita, baik menjual, maupun memindahkan hak atas barang yang menjadi objek sengketa

b) Melepaskan barang yang disimpan atas perintah hakim; dan

c) Menyembunyikan barang yang dilepaskan dari sitaan. ${ }^{19}$

Adapun beberapa barang yang tidak dapat dijadikan sebagai objek sita yaitu hewan dan perkakas yang sungguh-sungguh dipergunakan menjalankan pencaharian debitor. ${ }^{20}$

Penyitaan dapat dibedakan menjadi beberapa macam, yaitu:

1. Sita revindikasi (Revindicatoir). Revindicatoir berasal dari perkataan revindiceer yang berarti mendapatkan. ${ }^{21}$ Sita revindikasi adalah penyitaan yang diminta oleh pemilik barang bergerak yang barangnya ada di tangan orang lain, baik secara lisan maupun secara tertulis kepada ketua pengadilan negeri di mana orang yang memegang barang tersebut tinggal. ${ }^{22}$ Sita revindikasi diatur dalam Pasal $226 \mathrm{HIR}$ dan 260 R.Bg. Sita revindikasi hanya terbatas pada harta yang berupa benda bergerak yang ada di tangan orang lain tanpa hak. Permintaan sita diajukan oleh pemilik agar benda tersebut dikembalikan kepadanya.

2. Sita marital (Maritale Beslag). Sita marital adalah penyitaan yang dilakukan untuk menjamin agar barang yang disita tidak dijual, untuk melindungi hak pemohon selama pemeriksaan sengketa perceraian di pengadilan berlangsung antara pemohon dan lawan dengan menyimpan atau membekukan barangbarang yang disita agar tidak jatuh kepada pihak ketiga. ${ }^{23}$ Sita marital diatur dalam Pasal 820 dan 823 Rv. HIR dan R.Bg tidak mengatur mengenai sita marital ini. Harta suami istri menurut Undang-Undang Nomor 1 Tahun 1974 tentang Perkawinan (UU Perkawinan) dibedakan menjadi dua, yaitu harta bersama dan harta bawaan. Harta kekayaan bersama yang menjadi hak bersama suami-istri, dan harta pribadi (bawaan) yang menjadi hak penuh secara perseorangan bagi suami atau istri. ${ }^{24}$ Sita marital hanya diperuntukkan pada harta bersama dan tidak dapat menjangkau harta bawaan. Penjualan harta bersama yang telah disita marital harus mendapatkan izin hakim terlebih dahulu berdasarkan putusan untuk menghindari kemungkinan pengalihan kepemilikan harta

Ibid., hlm.286.

Pasal 197 ayat (8) HIR.

Retno Wulansari Susanto dan Iskandar Oeripkartawinata, Hukum Acara Perdata dalam Teori dan Praktek, Cetakan Kesepuluh, Bandung: Mancar Maju, 2005, hlm. 103.

Marwan dan Jimmy, Op.cit., hlm. 575.

Ibid.

Pasal 35 UU Perkawinan. 
bersama selama proses perceraian sedang diperiksa di persidangan sehingga tidak merugikan salah satu pihak.

3. Sita conservatoir (conservatoir beslag). Sita conservatoir adalah sita jaminan terhadap barang milik debitor untuk menjamin dapat dilaksanakannya putusan perdata dengan menguangkan atau menjual barang debitor yang disita guna memenuhi tuntutan penggugat. ${ }^{25}$ Sita conservatoir diatur dalam Pasal 227 HIR dan 261 R.Bg. Objek sita jaminan dapat berupa barang bergerak dan barang tidak bergerak baik terhadap benda berwujud maupun tidak berwujud (lychammelijk on lychammelijk).

4. Sita penyesuaian (Vergelijkende Beslag). Barang yang telah diletakkan sita, tidak bisa dilakukan sita untuk yang kedua kalinya, akan tetapi dapat dilakukan sita penyesuaian, sesuai yang tertuang dalam Pasal 436 Rv. Tata cara sita penyesuaian ada pada Putusan Mahkamah Agung Nomor 1326 K/Sip/1981.

5. Sita eksekusi (Executorial Beslag). Sita eksekusi merupakan sita pelaksanaan yaitu penyitaan atas harta kekayaan pihak yang dikalahkan dalam perkara perdata, baik berupa barang bergerak atau barang tidak bergerak untuk melaksanakan keputusan hakim yang telah memperoleh kekuatan hukum tetap. ${ }^{26}$ Tata cara dan syarat-syarat sita eksekusi diatur dalam Pasal 197 HIR atau Pasal208 R.Bg. Sita eksekusi dibedakan menjadi:

a. Sita Eksekusi Langsung, yakni sita eksekusi yang langsung diletakkan atas barang bergerak dan barang tidak bergerak milik debitur atau pihak yang kalah; dan

b. Sita Eksekusi yang Tidak Langsung, adalah sita eksekusi yang berasal dari sita jaminan yang telah dinyatakan sah dan berharga dan dalam rangka eksekusi otomatis berubah menjadi sita eksekusi. ${ }^{27}$

6. Sita umum dalam kepailitan. Sita umum dalam kepailitan adalah sita yang dilakukan atas seluruh harta debitor baik yang ada sekarang maupun yang akan ada di kemudian hari dengan tujuan, hasil penjualan dari harta tersebut dapat dibagikan secara adil dan proporsional di antara sesama para kreditor sesuai dengan besarnya piutang dari masing-masing kecuali di antara mereka mempunyaialasan untuk didahulukan. ${ }^{28}$

\footnotetext{
Marwan dan Jimmy, Op.cit., hlm. 575.

Ibid.

http://www.pta-makassarkota.go.id/index.php?option=com_content\&view=article\&id=356:macammacam-sita-dalam-hukum-perdata\&catid=1:berita\&Itemid=180, diakses 31 Januari 2017, pukul 21:52 WIB.

Pasal 1131 dan 1132 KUHPerdata.
} 
7. Sita pidana. Sita pidana atau disebut juga penyitaan adalah serangkaian tindakan penyidik untuk mengambil alih atau menyimpan di bawah penguasaannya benda bergerak atau tidak bergerak, berwujud atau tidak berwujud untuk kepentingan pembuktian dalam penyidikan, penuntutan, dan peradilan. ${ }^{29}$

\section{Sita Umum Kepailitan}

Kepailitan adalah sita umum atas semua harta kekayaan debitor pailit yang pengurusan dan pemberesannya dilakukan oleh kurator di bawah pengawasan hakim pengawas sebagaimana diatur di dalam UU KPKPU. ${ }^{30}$ Sita umum (public attachment, gerechtelijk beslag) dilakukan terhadap seluruh harta debitor agar dicapainya suatu perdamaian antara debitor dengan para kreditornya atau agar harta tersebut dapat dibagi-bagi secara adil di antara para kreditornya. ${ }^{31}$

Sita umum berlaku atas seluruh harta debitor baik yang sudah ada maupun yang akan ada selama proses kepailitan. ${ }^{32}$ Harta debitor menjadi jaminan bersama bagi semua kreditor terhadapnya hasil penjualan barang-barang itu dibagi menurut perbandingan piutang masing-masing kecuali bila di antara para kreditor tersebut mempunyai alasan-alasan sah untuk didahulukan. ${ }^{33}$ Harta debitor menjadi tanggungan atas segala perikatan yang dilakukannya, ${ }^{34}$ meskipun harta tersebut tidak berkaitan langsung dengan perikatan yang dilakukan debitor tersebut. Hukum memberikan kepastian bahwa harta tersebut menjadi jaminan bersama-sama untuk para kreditornya yang kemudian akan dibagikan menurut proporsi piutang masing-masing kecuali terdapat alasan untuk didahulukan. ${ }^{35}$ Ini sebagai jaminan keadilan bagi para kreditor apabila debitor tidak mampu memenuhi kewajibannya, baik kewajiban yang timbul dari perjanjian atau kewajiban yang timbul dari undangundang. Hal ini, dalam hukum kepailitan tertuang dalam prinsip paritas creditorium. Kewajiban yang dimaksud dalam prinsip paritas creditorium, hanya terbatas pada kewajiban dalam bidang harta kekayaan saja, kewajiban dalam hukum keluarga tidak termasuk. Jaminan hanya terbatas hak yang terdapat dalam bidang harta kekayaan saja, hak dalam bidang hukum keluarga tidak dapat dijadikan jaminan.

Setiap kreditor memiliki hak yang sama untuk mendapatkan pelunasan atas piutangnya. Debitor yang wanprestasi berakibat pada harta yang dimilikinya akan dijadikan jaminan pemenuhan prestasinya. Apabila kreditor merasa haknya belum dipenuhi oleh debitor, maka debitor dapat digugat oleh kreditor untuk memenuhi

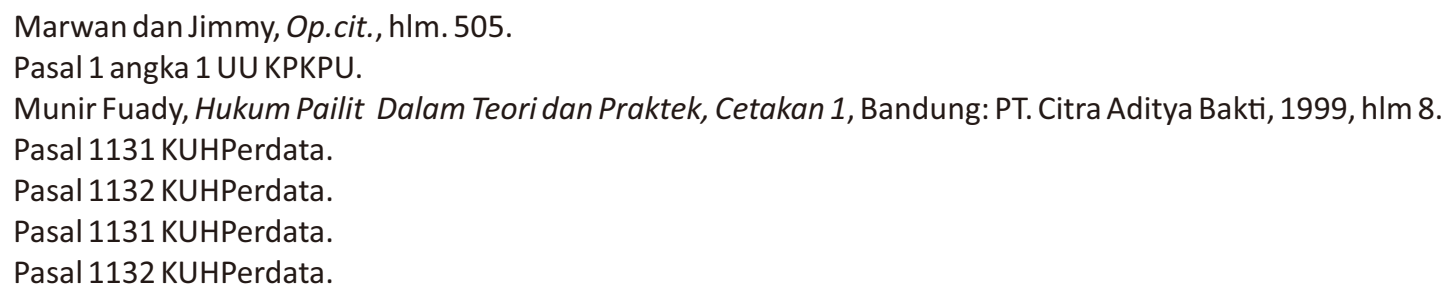


prestasinya secara perdata pada pengadilan negeri dan seluruh harta debitor menjadi sumber pelunasan utang tersebut. ${ }^{36}$ Semua kreditor mempunyai hak sama atas harta debitor. Harta debitor yang telah disita kemudian dieksekusi dan uang hasil penjualan akan dibagikan kepada para kreditornya sesuai dengan besar kecil piutang masing-masing (sesuai proporsi masing-masing), kecuali jika kreditor mempunyai alasan untuk didahulukan. Hukum kepailitan menuangkan hal tersebut dalam prinsip pari passu pro rata parte.

Menurut Kartini Muljadi, kreditor yang berhak mendapatkan pemenuhan perikatan harus mendapat pemenuhan perikatan dari debitor secara pari passu dan pro rata. Pari passu adalah para kreditor yang mempunyai hak dari debitornya secara bersama-sama memperoleh pelunasan tanpa ada yang didahulukan. ${ }^{37}$ Pro rata ialah proporsional yang dihitung berdasarkan pada besarnya piutang masingmasing dibanding dengan piutang mereka secara keseluruhan yaitu harta kekayaan yang dimilik debitor. ${ }^{38}$

Alasan untuk didahulukan adalah kreditor yang mempuyai hak istimewa dan hak jaminan. Kreditor yang memiliki hak istimewa dan hak jaminan mempunyai kedudukan yang lebih tinggi dari kreditor yang lainnya dalam hal pelunasan piutangnya. ${ }^{39}$ Alasan untuk didahulukan ini berupa hak yang dimiliki kreditor atas hak kebedaan berupa jaminan dari perikatan yang telah dibuat dengan debitor atau karena ditentukan oleh undang-undang. Hukum kepailitan dalam hal ini menganut prinsip structured prorata (structured creditor), yaitu prinsip yang membagi kreditor menjadi tiga golongan. Pembagian golongan kreditor tersebut adalah:

1. Krediitor preferen (secured creditor) adalah kreditor pemegang hak istimewa;

2. Kreditor separatis adalah pemegang hak jaminan; dan

3. Kreditor konkuren (unsecured creditor) adalah kreditor biasa, kreditor yang tidak memegang hak istimewa ataupun hak jaminan.

Kreditor yang termasuk dalam klasifikasi kreditor konkuren akan mendapat pelunasan utang paling akhir setelah sebelumnya dilakukan pelunasan untuk kreditor istimewa dan kreditor separatis. Hak istimewa adalah suatu hak yang diberikan oleh undang-undang kepada kreditor sehingga tingkatannya lebih tinggi dari kreditor lainnya, semata-mata berdasarkan sifat piutangnya. Kreditor pemegang hak istimewa mendapatkan jaminan pelunasan utang terlebih dahulu dari kreditor pemegang hak jaminan, setelah itu barulah kreditor biasa/konkuren yang mendapatkan kesempatan pemenuhan piutangnya.

Hadi M. Shubhan, Hukum Kepailitan Prinsip, Norma dan Praktik di Pengadilan, Jakarta: Kencana Prenada Media Group, 2012, hlm. 28.

Ibid., hlm. 5 .

Ibid.

Pasal 1134 KUHPerdata. 
Pasal 1133 KUHPerdata menyebutkan bahwa seorang kreditor dapat didahulukan pelunasan utangnya dari kreditor yang lainnya apabila:

1. Tagihan kreditor yang bersangkutan berupa hak istimewa;

2. Tagihan kreditor yang bersangkutan berupa hak gadai;

3. Tagihan kreditor yang bersangkutan berupa hak hipotek;

Adapun hak istimewa yang harus didahulukan pelunasannya adalah:

1. Hak istimewa yang dimaksud Pasal 1137 KUHPerdata, yaitu hak tagihan dari kas negara, kantor lelang dan badan publik lainnya yang dibentuk oleh pemerintah dan mengenai jangka waktu berlakunya hak tersebut ditentukan oleh undangundang khusus mengenai hal itu;

2. Utang pajak menurut Pasal 21 Undang-Undang Nomor 9 Tahun 1994 tentang Perpajakan;

3. Hak istimewa yang dimaksud Pasal 1139 KUHPerdata, yaitu biaya perkara yang semata-mata disebabkan karena suatu penghukuman untuk melelang suatu benda bergerak atau benda tidak bergerak;

4. Hak istimewa yang dimaksud Pasal 1149 angka 1 KUHPerdata, yaitu biaya-biaya perkara yang semata-mata disebabkan karena pelelangan dan penyelesaian warisan; dan

5. Imbalan kurator yang dimaksud UU KPKPU.

Sejak diputusnya kepailitan debitor berakibat debitor tidak lagi berhak menguasai, menggunakan, atau memindahtangankan hak atas benda serta mengagunkan benda yang merupakan harta pailit tersebut. ${ }^{40}$ Kepailitan adalah sita umum atas harta debitor baik yang ada pada saat putusan kepailitan maupun harta yang akan diperoleh selama kepailitan. ${ }^{41}$ Harta debitor yang disita umum adalah harta debitor baik yang berupa barang bergerak maupun barang tidak bergerak yang diperoleh sejak putusan pailit diucapkan dan seluruh harta yang diperoleh selama proses kepailitan. ${ }^{42}$

Sitaan terhadap seluruh kekayaan debitor merupakan bagian dari pengelolaan harta pailit (management of estate) yang dikelola berdasarkan suatu metode sistematik untuk mengurus harta kekayaan debitor selama menunggu proses kepailitan. ${ }^{43}$ Sita umum dilakukan dengan cara mengontrol semua harta kekayaan debitor dengan menunjuk kurator. Kurator berwenang melaksanakan tugas pengurusan dan/atau pemberesan atas harta pailit sejak tanggal pailit diucapkan. ${ }^{44}$

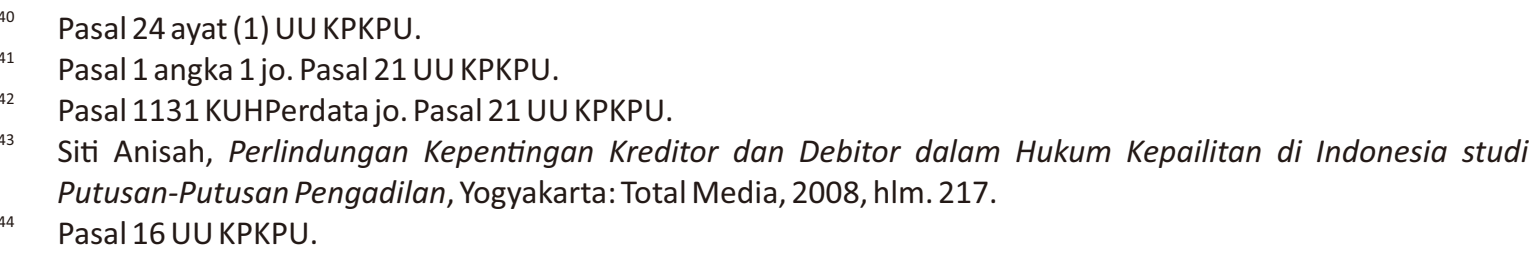


Debitor demi hukum kehilangan hak untuk menguasai dan mengurus kekayaannya sejak putusan pailit diucapkan. ${ }^{45}$ Sejak putusan pailit diucapkan, debitor menjadi tidak cakap lagi untuk mengurus dan melakukan perbuatan hukum terhadap hartanya sehingga diperlukan pengelola atas harta tersebut. Kurator ditunjuk oleh hakim pada saat putusan pailit diucapkan.

Sita umum dimaksudkan untuk mencegah debitor melakukan perbuatanperbuatan yang dapat merugikan kepentingan para kreditornya ${ }^{46}$ dan menghentikan lalu lintas transaksi terhadap harta pailit oleh debitor yang mungkin merugikan para kreditornya sehingga harta tersebut dapat dimanfaatkan bagi kepentingan para kreditornya. Selain itu, dilakukannya sita umum menjamin agar harta debitor tidak diperebutkan oleh para kreditornya. ${ }^{47}$ Ketika kreditor mengeksekusi hartanya secara sendiri-sendiri akan merugikan debitor dan kreditor yang lainnya sehingga penguasaan atas harta pailit perlu ditaruh di bawah penguasaan pengadilan. Hal ini tertuang dalam prinsip debt collection yaitu utang debitor harus segera dibayar dengan harta yang dimiliki oleh debitor sesegera mungkin agar keditor tidak mengklaim hartanya secara sendiri-sendiri dan untuk menghindari iktikad buruk dari debitor dengan cara menyembunyikan dan menyelewengkan harta bendanya yang sebenarnya diagunkan sebagai jaminan kepada para kreditornya. ${ }^{48}$

Sita umum ini terjadi demi hukum sehingga tidak memerlukan suatu tindakan secara khusus atau tindakan hukum tertentu seperti halnya sita lainnya dalam hukum perdata. ${ }^{49}$ Semua penyitaan yang telah dilakukan menjadi hapus dan jika diperlukan Hakim Pengawas harus memerintahkan pencoretannya. ${ }^{50}$

\section{Sita Pidana}

Sita dalam hukum pidana adalah penyitaan yang dilakukan terhadap barang bergerak/tidak bergerak milik seseorang, untuk mendapatkan bukti dalam perkara pidana. ${ }^{51}$ Penyitaan merupakan serangkaian tindakan penyidik untuk mengambil alih dan/atau menyimpan di bawah penguasaannya benda bergerak atau tidak bergerak, berwujud atau tidak berwujud untuk kepentingan pembuktian dalam penyidikan, penuntutan, dan peradilan. ${ }^{52}$

Penyitaan yang dilakukan merupakan mengambilan dan perampasan serta penguasaan hak milik orang lain. Penyitaan hanya dapat dilakukan oleh penyidik

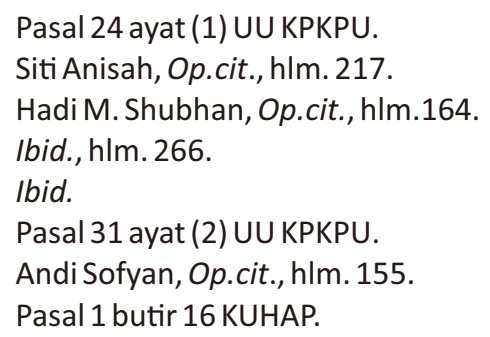


atas izin dari ketua pengadilan negeri setempat. ${ }^{53} \mathrm{Hal}$ ini dilakukan sebagai bentuk batasan dalam pelaksanaannya karena tidak dapat dipungkiri bahwa perampasan hak milik orang lain merupakan pelanggaran hak asasi manusia yang pokok. ${ }^{54}$ Pasal 7 ayat (1) huruf d KUHAP menyatakan bahwa penyidik karena kewajibannya mempunyai wewenang untuk melakukan penyitaan.

Penyitaan digunakan oleh penyidik untuk mengamankan benda yang berkaitan dengan perkara yang sedang disidik, dituntut, atau diperadilankan agar tidak hilang atau dimusnahkan oleh tersangka atau terdakwa untuk dijadikan barang bukti dalam perkara tersebut. Perkara pidana yang akan diajukan di depan pengadilan harus dilengkapi dengan barang bukti. Penyidik berwenang memerintahkan kepada orang yang menguasai benda yang dapat disita, menyerahkan benda tersebut kepadanya untuk kepentingan pemeriksaan dan kepada yang menyerahkan benda itu harus diberikan surat tanda penerimaan. ${ }^{55}$

Penyitaan dalam hukum acara pidana merupakan upaya paksa yang dilakukan penyidik untuk:

1. Mengambil atau merampas sesuatu barang tertentu dari seorang tersangka, pemegang, atau penyimpan. Tapi perampasan yang dilakukan dibenarkan hukum dan dilaksanakan menurut aturan undang-undang, bukan perampasan liar dengan cara melawan hukum (wederwchtelyk);

2. Setelah barangnya diambil atau dirampas oleh penyidik, barang tersebut ditaruh atau disimpan di bawah kekuasaannya. ${ }^{56}$

Benda-benda yang dapat disita diatur dalam Pasal 39 Ayat (1) KUHAP, sebagai berikut:

1. Benda atau tagihan tersangka atau terdakwa yang seluruh atau sebagian diduga diperoleh dari tindak pidana atau sebagai hasil dari tindak pidana;

2. Benda yang telah dipergunakan secara langsung untuk melakukan tindak pidana atau untuk mempersiapkannya;

3. Benda yang dipergunakan untuk menghalang-halangi penyidikan tindak pidana;

4. Benda yang khusus dibuat atau diperuntukkan melakukan tindak pidana; dan

5. Benda lain yang mempunyai hubungan langsung dengan tindak pidana yang dilakukan.

Benda-benda tersebut harus disimpan dalam rumah penyimpanan benda sitaan negara (RUP BASAN). ${ }^{57}$ Penyimpanan benda sitaan dilaksanakan dengan sebaik-baiknya dan tanggung jawab atasnya ada pada pejabat yang berwenang

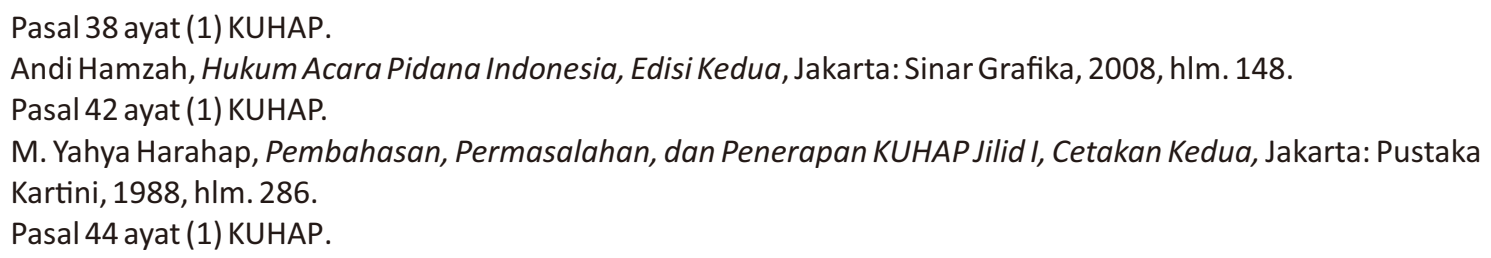


sesuai dengan tingkat pemeriksaan dalam proses peradilan dan benda tersebut dilarang untuk dipergunakan oleh siapa pun juga. ${ }^{58}$ Selama belum ada rumah penyimpanan benda sitaan negara di tempat yang bersangkutan, penyimpanan benda sitaan tersebut dapat dilakukan di kantor kepolisian pemerintah dan dalam keadaan memaksa di tempat penyimpanan lain atau tetap di tempat semula benda itu disita. ${ }^{59}$ Benda yang berada dalam sitaan karena perkara perdata atau karena pailit dapat juga disita untuk kepentingan penyidikan, penuntutan, dan mengadili perkara pidana, sepanjang memenuhi ketentuan Pasal 39 ayat (1) KUHAP. ${ }^{60}$ Terdapat beberapa bentuk penyitaan menurut KUHAP, yaitu:

1. Penyitaan biasa, penyitaan dengan bentuk dan tata cara biasa ini merupakan aturan hukum penyitaan;

2. Penyitaan dalam keadaan perlu dan mendesak sebagai pengecualian dari penyitaan biasa, maka Pasal 38 ayat (2) KUHAP memberi kemungkinan untuk melakukan penyitaan tanpa melalui tata cara biasa;

3. Penyitaan dalam keadaan tertangkap tangan. Penyitaan dalam keadaan tertangkap tangan diatur dalam Pasal 40 dan Pasal 41 KUHAP;

4. Penyitaan terhadap surat atau tulisan lain Penyitaan terhadap surat atau tulisan lain diatur dalam Pasal 43 KUHAP;

Prosedur dan tata cara penyitaan dijabarkan sebagai berikut:

1. Penyitaan hanya boleh dilakukan penyidik dengan surat izin ketua pengadilan negeri setempat sebelum melakukan penyitaan; ${ }^{61}$

2. Dalam keadaan yang sangat perlu dan mendesak, penyidik harus segera bertindak dan tidak mungkin untuk mendapatkan surat izin terlebih dahulu, tanpa mengurangi ketentuan ayat (1) penyidik dapat melakukan penyitaan hanya atas benda bergerak dan untuk itu wajib segera melaporkan kepada ketua pengadilan negeri setempat guna memperoleh persetujuannya; ${ }^{62}$

3. Sebelum melakukan penyitaan, Penyidik menunjukkan tanda pengenalnya kepada orang dari mana benda itu disita terlebih dahulu; ${ }^{63}$

4. Penyidik memperlihatkan benda yang akan disita kepada orang dari mana benda itu akan disita atau kepada keluarganya dan dapat minta keterangan tentang benda yang akan disita itu dengan disaksikan oleh kepala desa atau ketua lingkungan dengan dua orang saksi ${ }^{64}$

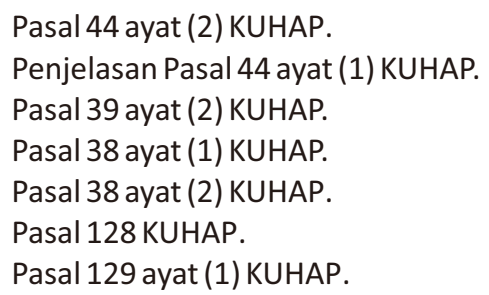


5. Penyidik membuat berita acara penyitaan yang dibacakan terlebih dahulu kepada orang darimana benda itu disita atau keluarganya dengan diberi tanggal dan ditandatangani oleh penyidik maupun orang atau keluarganya dan/atau kepala desa atau ketua lingkungan dengan dua orang saksi; ${ }^{65}$

6. Apabila orang dari mana benda itu disita atau keluarganya tidak mau membubuhkan tandatangannya hal itu dicatat dalam berita acara dengan menyebut alasannya; ${ }^{66}$

7. Turunan dari berita acara itu disampaikan oleh penyidik kepada atasannya, orang dari mana benda itu disita atau keluarganya, dan kepala desa; ${ }^{67}$

8. Benda sitaan sebelum dibungkus, dicatat berat dan/atau jumlah menurut jenis masing-masing, ciri maupun sifat khas, tempat, hari dan tanggal penyitaan, identitas orang dari mana benda itu disita dan lain-lainnya yang kemudian diberi hak dan cap jabatan dan ditandatangani oleh penyidik; ${ }^{68}$

9. Dalam hal benda sitaan tidak mungkin dibungkus, penyidik memberi catatan sebagaimana dimaksud dalam Pasal 130 ayat (1) KUHAP, yang ditulis di atas label yang ditempelkan dan/atau dikaitkan pada benda tersebut; ${ }^{69}$

10.Dalam hal sesuatu tindak pidana sedemikian rupa sifatnya sehingga ada dugaan kuat dapat diperoleh keterangan dari berbagai surat, buku atau kitab, daftar dan sebagainya, penyidik segera pergi ke tempat yang dipersangkakan untuk menggeledah, memeriksa surat, buku atau kitab, daftar dan sebagainya dan jika perlu menyitanya. ${ }^{70}$ Dengan merujuk pada ketentuan yang diatur dalam Pasal 129 KUHAP. $^{71}$

Berakhirnya penyitaan:

1. Penyitaan dapat berakhir sebelum ada putusan hakim, apabila

a. kepentingan penyidikan dan penuntutan tidak memerlukannya lagi;

b. perkara tersebut tidak jadi dituntut karena tidak cukup bukti atau ternyata tidak merupakan tindak pidana;

c. perkara tersebut dikesampingkan untuk kepentingan umum atau perkara tersebut ditutup demi hukum, kecuali apabila benda itu diperoleh dari suatu tindak pidana atau yang dipergunakan untuk melakukan suatu tindak pidana. $^{72}$

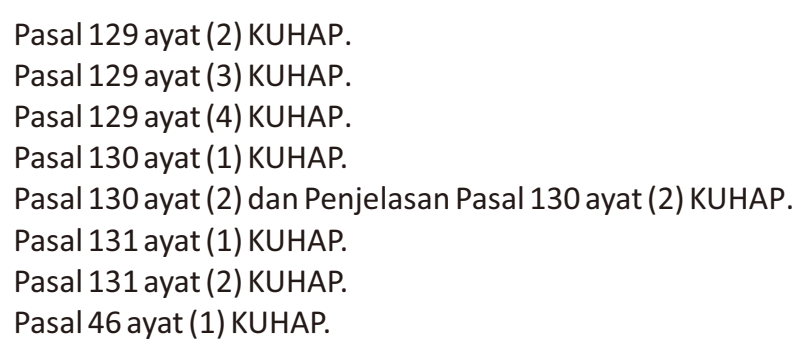


Terhadap benda yang dikenakan penyitaan, dikembalikan kepada orang atau kepada mereka dan siapa benda itu disita, atau kepada orang atau kepada mereka yang paling berhak. ${ }^{73}$

2. Penyitaan berakhir setelah putusan hakim, maka benda yang dikenakan penyitaan dikembalikan kepada orang atau kepada mereka yang disebut dalam putusan tersebut kecuali jika menurut putusan hakim benda itu dirampas untuk negara, untuk dimusnahkan atau untuk dirusakkan sampai tidak dapat dipergunakan lagi atau jika benda tersebut masih diperlukan sebagal barang bukti dalam perkara lain. ${ }^{74}$

\section{E. Sita Umum Kepailitan Mendahului Sita Pidana dalam Pemberesan Harta Pailit}

Sejak putusan pailit diucapkan, debitor tidak dapat mengusai dan mengelola hartanya. Pengelolaan harta tersebut berpindah ke tangan kurator. Sejak tanggal putusan pailit diucapkan pengurusan dan/atau pemberesan harta pailit berada di bawah wewenang kurator. ${ }^{75}$ Seluruh harta debitor baik yang ada sekarang maupun yang akan ada selama proses kepailitan menjadi harta pailit. Kurator bertugas untuk membereskan dan mengurus harta pailit tersebut kemudian membagikannya kepada para kreditornya berdasarkan proporsi piutang masing-masing.

Pada saat debitor sudah dinyatakan pailit maka segala penetapan pelaksanaan Pengadilan terhadap setiap bagian dari kekayaan Debitor yang telah dimulai sebelum kepailitan, harus dihentikan seketika dan sejak itu tidak ada suatu putusan yang dapat dilaksanakan termasuk atau juga dengan menyandera Debitor. ${ }^{76}$ Semua penyitaan yang telah dilakukan menjadi hapus dan jika diperlukan Hakim Pengawas harus memerintahkan pencoretannya. ${ }^{77}$ Debitor yang sedang dalam penahanan harus dilepaskan seketika setelah putusan pernyataan pailit diucapkan. ${ }^{78}$

Sita pidana adalah serangkaian tindakan penyidik untuk mengambil alih dan/atau menyimpan di bawah penguasaannya benda bergerak atau tidak bergerak, berwujud atau tidak berwujud untuk kepentingan pembuktian dalam penyidikan, penuntutan, dan peradilan. ${ }^{79}$ Benda yang disita tersebut diambil oleh penyidik dari kekuasaan pemilik yang akan digunakan sebagai barang bukti untuk kepentingan pemeriksaan, penuntutan, dan peradilan. Penyitaan dimaksudkan agar benda tersebut aman, tidak dapat dihilangkan atau dimusnahkan oleh tersangka atau terdakwa.

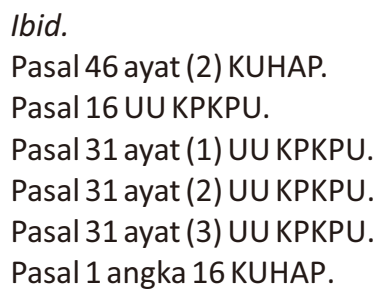


Pasal 31 ayat (2) UU KPKPU menyebutkan seluruh sita dihentikan ketika putusan pailit telah diucapkan, jika diperlukan Hakim Pengawas harus memerintahkan pencoretannya. Sejak putusan pailit diucapkan seluruh sita yang ada pada sebuah benda berakhir dan digantikan sita umum kepailitan. Hal ini dimaksudkan untuk melindungi harta debitor pailit dari kemungkinan kecurangan yang dilakukan kreditor maupun debitor.

Pasal 39 ayat (2) KUHAP menyatakan bahwa benda yang berada dalam perkara kepailitan dapat disita oleh penyidik demi kebutuhan penyidikan, penuntutan, dan mengadili perkara pidana. Demi kebutuhan penyidikan, penuntutan, dan peradilan harta debitor pailit yang sudah disita umum dapat disita lagi oleh penyidik untuk menjamin keamanannya. Harta tersebut akan dijadikan barang bukti dalam penyidikan, penuntutan, dan peradilan sehingga keamanannya harus terjamin.

Di sini telah terjadi tumpang tindih antara hukum kepailitan mengenai sita umum kepailitan yang diatur dalam Pasal 31 ayat (2) UU KPKPU dengan hukum acara pidana mengenai penyitaan yang diatur dalam Pasal 39 ayat (2) KUHAP. Hukum kepailitan mengatur bahwa sejak diucapkan putusan pailit oleh hakim maka seluruh sita terhadap harta pailit menjadi tidak berlaku lagi. Sedangkan hukum acara pidana mengatur bahwa harta pailit dapat disita pidana. Apabila harta yang berada di dalam proses pailit dan dilakukan sita umum disita oleh penyidik maka harta tersebut tidak dapat dibereskan dan dibagi kepada para kreditornya. Hal ini akan merugikan para kreditor. Namun, apabila tidak dilakukan penyitaan oleh penyidik, penyidik akan kesulitan dalam melakukan penyidikan, penuntutan, dan pengajuan perkara ke pengadilan karena harta tersebut merupakan barang bukti.

Terdapat beberapa pandangan menurut para ahli dalam hal sita pidana dan sita umum kepailitan yang terjadi pada harta pailit manakah yang harus didahulukan, yaitu:

1. Perwakilan Divisi Hukum Polri AKBP W. Marbun mengatakan sita pidana lebih didahulukan daripada sita umum pailit. Bahkan, sita pidana tetap dapat dilakukan meskipun barang tersebut telah dilakukan sita umum pailit oleh kurator. Menurutnya, pada asasnya kepentingan hukum publik lebih diutamakan daripada hukum keperdataan. ${ }^{80}$ Benda yang berada dalam sitaan karena perkara perdata atau pailit dapat juga disita untuk kepentingan penyidikan, penuntutan, dan mengadili perkara pidana sepanjang memenuhi ketentuan Pasal 39 ayat (1) KUHAP; ${ }^{81}$

2. Guru Besar Hukum Pidana Fakultas Hukum Universitas Gadjah Mada Edward Omar Sharif Harief mengatakan hukum publik lebih diutamakan daripada hukum

\footnotetext{
so Hukum Online, http://www.hukumonline.com/berita/baca/lt51836ecd9bbf8/prokontra-sita-pidana-vs-sitaumum-pailit, diakses 25 Januari 2017.

81 Pasal 39 ayat (2) KUHAP.
} 
privat. Hukum pidana adalah hukum publik. Hukum publik memiliki karakteristik pemaksaan oleh aparat negara. Apabila barang yang hendak disita penyidik adalah barang yang telah di bawah kekuasaan kurator, barang tersebut tetap disita mengingat sifat dan karakter hukum pidana tersebut. Namun, barang yang akan disita tersebut tidak secara otomatis diambil alih oleh penyidik. Terdapat ada dua cara yang dapat dilakukan jika terjadi benturan kewenangan. Pertama, polisi dapat menyita barang yang hendak disita, tetapi penguasaannya tetap berada pada pihak yang telah menyita pertama kali, dalam hal ini adalah kurator. Kedua, menunggu salah satu perkara selesai; ${ }^{82}$

3. Direktorat Jenderal Administrasi Hukum Umum Kementerian Hukum dan HAM, Freddy Harris mengatakan jika telah terjadi sita umum kepailitan, sita pidana tidak dapat dilakukan. Hukum melarang untuk sita rangkap pada satu objek sita. Apabila ada dua permohonan pelaksanaan atau lebih yang diajukan sekaligus kepada debitur, cukup dibuatkan satu berita acara penyitaan saja. Tujuan sita umum adalah untuk menjaga hak para pihak agar debitor tidak menggelapkan atau membawa barang-barangnya dari kreditor. Begitu juga halnya dengan sita pidana. Tidak ada hal yang berbeda dari dua hal ini. Hanya saja, untuk kepailitan, penyitaan aset debitor dalam perkara kepailitan bertujuan untuk menambah boedel pailit dan melindungi kreditor-kreditor konkuren lainnya. Sedangkan sita pidana, hanya untuk pembuktian semata. Penyitaan menurut Pasal 39 ayat (2) KUHAP bukan berarti barang yang disita berpindah penguasaan ke bawah penyidik. Akan tetapi, penyidik dapat me-register kepentingannya kepada kurator. Artinya, penyidik sebagai penyelamat kepentingan negara didudukkan sebagai kreditor preferen layaknya pajak; ${ }^{83}$

4. Pengajar Hukum Kepailitan Fakultas Hukum Universitas Airlangga M. Hadi Subhan berpendapat bahwa kedudukan sita umum lebih tinggi daripada sita pidana. Intisari dari hukum kepailitan adalah sita umum atas seluruh kekayaan debitor. Putusan pernyataan pailit berakibat segala penetapan pelaksanaan pengadilan terhadap bagian dari harta kekayaan debitor yang telah dimulai sejak kepailitan harus dihentikan seketika. ${ }^{84}$ Putusan pengadilan hanya dapat dibatalkan dengan putusan pengadilan. Sita umum kepailitan adalah putusan hakim sedangkan sita pidana adalah penetapan hakim. Sehingga, penetapan sita pidana tidak dapat menghapuskan putusan majelis hakim pengadilan niaga. ${ }^{85}$

\footnotetext{
Hukum Online, Loc. cit.

Pasal 201 HIR dan 463 Rv.

Pasal 31 UU KPKPU.

Hukum Online, Loc. cit.
} 
Menurut Prof. Sudikno Mertokusumo, dalam menegakkan hukum harus memperhatikan tiga unsur penegakan hukum, yaitu:

1. Keadilan (gerechtigkeit). Penegakan hukum harus memperhatikan keadilan. ${ }^{86}$ Peraturan harus dibuat adil. Harus ada keseimbangan antara kepentingankepentingan yang dilindungi, setiap orang memperoleh sebanyak mungkin yang menjadi bagiannya. ${ }^{87}$

Aristoteles mengajarkan dua macam keadilan, yaitu:

a. Keadilan distributief, yaitu keadilan yang memberikan kepada tiap-tiap orang menurut jatah jasanya. Setiap orang tidak mendapatkan bagian yang sama banyak. Keadilan distributif ini bukan menggunakan persamaan namun kesebandingan.

b. Keadilan commutatief, yaitu keadilan yang memberikan pada setiap orang sama banyaknya dengan tidak mengingat jasa-jasa perseorangan. Keadilan commutatief mengutamakan persamaan.

2. Kepastian hukum (rechtssicherheit). Fiat justitia et pereat mundus (meskipun langit runtuh, hukum harus ditegakkan), bagaimana hukumnya itulah yang harus berlaku, pada dasarnya tidak boleh menyimpang. ${ }^{88}$ Kepastian hukum merupakan perlindungan yustisiabel terhadap tindakan sewenang-sewenang. Seseorang dapat memperoleh sesuatu yang diharapkan dalam keadaan tertentu. Ketertiban masyarakat akan tercapai bila kepastian hukum tercipta sebagaimana mestinya. $^{89}$

3. Kemanfaatan (zweckmassigkeit). Penegakan hukum harus memberi manfaat atau kegunaan kepada masyarakat. Jangan sampai penegakan hukum menimbulkan keresahan dalam masyarakat. ${ }^{90}$

Ketiga unsur penegakan hukum harus diperhatikan semuanya, tidak dapat hanya memperhatikan kepastian hukum, kemanfaatan hukum, atau keadilan hukum saja. Ketiga unsur tersebut harus diperhatikan secara seimbang tidak boleh berat pada satu unsur saja. Sehingga penegakan hukum dapat berjalan sebagai mana mestinya dan dapat tujuan hukum dapat tercapai untuk mengatur pergaulan hidup secara damai. ${ }^{91}$

Melihat ketiga unsur di atas, seharusnya sudah dapat ditentukan sita umum kepailitan atau sita pidana yang harus didahulukan terlebih dahulu.

Asep Warlan Yusuf, Hukum dan Keadilan, Padjadjaran Jurnal Ilmu Hukum, Volume 2, Nomor 1, 2015, hlm. 1-13.

L.J. Van Apeldoorn, Pengantar Ilmu Hukum, Cetakan Ke-29, Jakarta: Pradnya Paramita, 2001, hlm. 11.

8 Sudikno Mertokusumo, Mengenal Hukum Suatu Pengantar, Edisi Revisi, Yogyakarta: Cahaya Atma Pustaka, 2010, hlm. 207.

Ibid.

Ibid.

Ibid. 
1. Keadilan. Pemberlakuan sita umum keadilan bagi kreditor dapat terlaksana secepatnya setelah selama beberapa waktu kreditor tidak mendapatkan haknya sebagaimana mestinya karena debitor tidak memenuhi kewajibannya, namun hal ini akan menyebabkan ketidakadilan bagi masyarakat karena tujuan dari hukum pidana untuk membalaskan perbuatan seseorang yang telah mengganggu masyarakat dan kepentingan serta memberikan efek jera tidak akan terlaksana. Apabila sita pidana diberlakuan terlebih dahulu maka terjadi pelanggaran hak kreditor yang seharusnya mendapatkan pelunasan piutang;

2. Kemanfaatan. Manfaat yang akan didapat apabila sita umum didahulukan adalah kepentingan kreditor atas harta pailit dapat terpenuhi. Harta pailit dapat segera dibereskan dan dibagikan kepada para kreditornya. Masalah utang piutang dapat terselesaikan secepatnya dan seadil-adilnya sehingga perekonomian tidak akan terganggung baik perekonomian dalam segala kecil maupun dalam sekala besar. Manfaat yang akan didapat apabila sita pidana yang didahulukan adalah keamanan harta yang disita terjamin. Hasil penyitaan tersebut akan dijadikan sebagai barang bukti suatu tindak pidana. Hal ini juga akan memudahkan penyidikan. Namun, apabila sita umum ditetapkan terlebih dahulu dan kurator dapat menjamin negara ditempatkan sebagai kreditor pemegang hak istimewa untuk selalu didahulukan pemenuhan kewajibannya dapat dilakukan sita umum terlebih dahulu;

3. Kepastian hukum. Untuk mengetahui kepastian hukum dari sita pidana atau sita umum kepailitan yang harus didahulukan dalam pemberesan harta pailit kita harus melihat terlebih dahulu mengenai asas pembentukan dan penerapan peraturan perundang-undangan. Adapun asas-asas tersebut adalah:

a. Asas legalitas yaitu undang-undang tidak berlaku surut. Dalam hal ini, Pasal 39 ayat (2) KUHAP dan Pasal 31 UU KPKPU sama-sama merupakan peraturan yang sudah lama diundangkan jadi kedua peraturan tersebut harus dilaksanakan sebagaimana mestinya dan setiap perbuatan hukum harus tunduk kepada aturan tersebut;

b. Asas lex superior derogat legi inferiori yaitu peraturan yang lebih tinggi mengalahkan peraturan yang lebih rendah, atau apabila terjadi konflik atau pertentangan antara peraturan perundang-undangan yang tinggi dengan yang rendah maka yang tinggilah yang harus didahulukan.92 Dalam hal ini, Pasal 39 ayat (2) KUHAP dan Pasal 31 UU KPKPU mempunyai kedudukan yang sama tinggi dalam peraturan perundang-undangan karena kedua peraturan tersebut terdapat dalam peraturan dalam tingkatan undangundang;

Ferry Irawan Febriansyah, "Konsep Pembentukan Peraturan Perundang-undangan Di Indonesia”, Jurnal Perspektif, Volume XXI, Nomor 3 Tahun, 2016, hIm. 226. 
c. Asas Lex posterior derogat legi priori yaitu peraturan yang lebih baru mengalahkan peraturan yang lebih lama. Asas ini biasanya digunakan baik dalam hukum nasional maupun internasional. ${ }^{93}$ Dalam hal ini, Pasal 31 UU KPKPU merupakan peraturan yang baru apabila kita sandingkan dengan Pasal 39 ayat (2) KUHAP;

d. Asas Lex specialis derogat legi generali yaitu penafsiran hukum yang menyatakan bahwa hukum yang bersifat khusus atau lex specialis mengesampingkan hukum yang bersifat umum atau lex generalis. ${ }^{94}$ Pasal 31 UU KPKPU merupakan peraturan yang lebih khusus yaitu peraturan yang mengatur mengenai penyitaan terhadap harta pailit.

Tidak dapat dipungkiri dari ketiga nilai hukum di atas satu dengan yang lainnya terkadang tidak dapat disinkronkan dan saling berhadap-hadapan, walaupun demikian keadilan tetap harus diutamakan. Disusul dengan kemanfaatan dan kepastian hukum. Akan lebih adil ketika dilakukan sita umum terlebih dahulu karena di sini kreditor yang sudah lama menanti haknya dapat dengan segera mendapatkan haknya dan negara tidak perlu khawatir karena kurator dapat menjamin negara ditempatkan sebagai kreditor pemegang hak istimewa untuk selalu didahulukan pemenuhan kewajibannya.

\section{F. Penutup}

Sita umum kepailitan mendahului sita pidana karena dilihat dari keadilan hak kreditor terpenuhi dan tidak terdapat pelanggaran hak lagi. Dari segi kemanfaatan masalah utang piutang dapat terselesaikan secepatnya dan seadil-adilnya sehingga perekonomian tidak akan terganggu, baik perekonomian dalam segala kecil maupun dalam sekala besar. Sedangkan bagi negara, negara dapat dijadikan sebagai kreditor pemegang hak istemewa yang mendapatkan prioritas dalam pemberesan harta pailit. Dari segi kepastian hukum, Pasal 31 UU KPKPU yang menyebutkan mengenai semua sita diangkat sejak diucapkan kepailitan seorang debitor merupakan peraturan baru dan peraturan yang khusus dibandingkan peraturan sita pidana yang terdapat dalam Pasal 39 ayat (2) KUHAP.

\section{Daftar Pustaka}

\section{Buku}

Andi Sofyan dan Abd. Asis, Hukum Acara Pidana Suatu Pengantar, Cetakan Ke-2, Prenadamedia Group, Jakarta, 2014.

Hadi M. Shubhan, Hukum Kepailitan Prinsip, Norma dan Praktik di Pengadilan, Kencana Prenada Media Group, Jakarta, 2012.

93 Ibid. 
L.J. Van Apeldoorn, Pengantar Ilmu Hukum, Cetakan Ke-29, Pradnya Paramita, Jakarta, 2001.

Munir Fuady, Hukum Pailit Dalam Teori dan Praktek, Cetakan 1, PT. Citra Aditya Bakti, Bandung, 1999.

M. Marwan dan Jimmy P., Kamus Hukum Dictionary Of Law Complete Edition, Cetakan I, Reality Plublisher, Surabaya, 2009.

M. Yahya Harahap, Hukum Acara Perdata Tentang Gugatan, Persidangan, Penyitaan, Pembuktian dan Putusan Pengadilan, Cetakan Keempat, Sinar Grafika, Jakarta, 2006.

, Pembahasan, Permasalahan, dan Penerapan KUHAP Jilid I, Cetakan Kedua, Pustaka Kartini, Jakarta, 1988.

Retno Wulansari Susanto dan Iskandar Oeripkartawinata, Hukum Acara Perdata dalam Teori dan Praktek, Cetakan Kesepuluh, Mancar Maju, Bandung, 2005.

Siti Anisah, Perlindungan Kepentingan Kreditor dan Debitor dalam Hukum Kepailitan di Indonesia studi Putusan-Putusan Pengadilan, Total Media, Yogyakarta, 2008.

Sudikno Mertokusumo, Mengenal Hukum Suatu Pengantar, Edisi Revisi, Cahaya Atma Pustaka, Yogyakarta, 2010.

\section{Dokumen Lain}

Asep Warlan Yusuf, "Hukum dan Keadilan”, Padjadjaran Jurnal IImu Hukum, Volume 2, Nomor 1, 2015.

Ferry Irawan Febriansyah, "Konsep Pembentukan Peraturan Perundang-undangan Di Indonesia", Jurnal Perspektif, Volume XXI, Nomor 3 Tahun 2016.

Romli Atmasasmita, "Analisis Hukum Undang-Undang Nomor 8 Tahun 2010 Tentang Pencegahan Tindak Pidana Pencucian Uang", Padjadjaran Jurnal IImu Hukum, Volume 3 Nomor 1, 2016.

http://www.pta-makassarkota.go.id/index.php?option=com content\&view=article \&id=356: macam-macam-sita-dalam-hukum-perdata\&catid=1: berita\&ltemid=180, diakses 31 Januari 2017

Hukum Online, http://www.hukumonline.com/berita/baca/lt51836ecd9bbf8/prokontra-sita-pidana-vs-sita-umum-pailit, diakses 25 Januari 2017.

Kompas, http://nasional.kompas.com/read/2012/11/05/15163281/Mal.Serpong.Robert.Tantular.Diserahkan.ke.Kejagung diakses 15 Maret 2017.

\section{Dokumen Hukum}

Undang-Undang Nomor 1 Tahun 1974 tentang Perkawinan.

Undang-Undang Nomor 37 Tahun 2004 tentang Kepailitan dan Penundaan Kewajban Pembayaran Utang.

Kitab Undang-Undang Hukum Acara Pidana. 
Herizien Inlandsch Reglement (HIR).

Rechtreglement voor de Buitengewesten (Rbg).

Reglement op de Rechtvordering (Rv). 